\title{
European Universities and the ICT Industry
}

\author{
Vasile Baltac \\ Information Technology and Communications Association of Romania, Romania, \\ vasile.baltac@atic.org.ro
}

\begin{abstract}
Information and Communications Technologies (ICT) have a distinct and unique role to contribute to the overall advancement of Europe, in its efforts to ensure economic and social success. Europe needs continuous progress in information and communications technologies and its industry and universities contribute to this progress. The demand for professionals increases constantly and exceeds the offerings. Both in the industrial and university communities persists an opinion about a divorce between the formal existing educational institutions and the needs of ICT professionals by the industry. This divorce is considered by some to be at the origin of the scarcity of ICT professionals in many ICT specialties. While preparation of eSkills for basic ICT use is not the task of universities, but of high-schools, we may note also that there are still in several EU countries university graduates that do not have all the necessary basic skills to use ICT or E-business at work or at home. Policy makers, universities and industry have to increase investment in universities for preparing the right ICT skills. Europe has to bring its universities at the level of expectancy of the 12010 strategy.
\end{abstract}

Keywords: ICT industry, European universities, eSkills, certifications, CEPIS

\section{Why a Paper on Universities and ICT Industry?}

Information and Communications Technologies (ICT) have a distinct and unique role to contribute to the overall advancement of Europe, in its efforts to ensure economic and social success. This progress is based on the large deployment of technologies, a highly sophisticated workforce and the general training of users to fully exploit what the technologies offer. Entrepreneurship is fully embraced by enterprises in the ICT sector and the role of small and medium enterprises (SME) is remarkably important for the development of the sector, where challenge and competition are the main engines of growth.

Europe is under pressure from both the American and Asian continents. Higher salaries in Europe can be counterbalanced only by innovation and skills. The fresh 
developments in Eastern Europe hardly compensate the impact of new sources of ICT manpower in Asia and South America. Europe needs continuous progress in information and communications technologies and its industry and universities contribute to this progress. Industry delivers the technologies and applications, but the core elements are the skills, and professionals having these skills. There is no other industry with such a high rate of evolution reflected in changes in the skills, and in the need for retraining, during the working life of a person.

It is the role of European higher education institutions, generally called universities, to produce the needed skills. Universities have the primary distinct role in producing the professionals needed by the ICT industry and they have to continue to strengthen their vital role in this respect. Despite a significant quantitative and qualitative offering by European universities, the demand for professionals increases constantly and exceeds the offerings. Estimating supply and demand levels in 2010 and 2015, CEPIS believes that Europe would face shortages of up to 70,000 ICT practitioners (CEPIS, 2007).

The cooperation of European universities with the ICT industry is very important and is of interest not only to the two actors, but public authorities should also be actively engaged. CEPIS notes that there persists both in the industrial and university communities an opinion about a divorce between the formal existing educational institutions and the needs of ICT professionals by the industry. This divorce is considered by some to be at the origin of the scarcity of ICT professionals in many ICT specialties. Other opinions take into account the fact that too few young people in developed countries want to study engineering subjects, to supply the needs of the industry. On the other hand, ICT professional educational background needs to be multidisciplinary to address student needs and highly specialised to address industry needs, a hard to reconcile dilemma.

While preparation of eSkills for basic ICT use is not the task of universities, but of high-schools, CEPIS notes also that there are still in several EU countries university graduates that do not have all the necessary basic skills to use ICT or Ebusiness at work or at home.

Policy makers, universities and industry have to increase investment in universities for preparing the right ICT skills (Lamborghini, 2007). Most ICT graduates now come from Asia, a fact with deep impact on the future of the ICT industry.

Europe has to bring its universities at the level of expectancy of the i2010 strategy.

\subsection{University - ICT Industry Partnership}

The best way to interact between universities and the industry has been a much debated topic in Europe for decades. Universities enjoy, in general, a good relationship with the ICT industry. This is reflected in the high level of training of 
ICT graduates and in the various forms of cooperation between university and industry.

There are still voices that affirm that universities and industry do not cooperate at a sufficient level. There are similar opinions in the USA, even if for European observers the US university-industry relations seem to be an ideal (Bavec, 2007). It is certain that universities and industry have different objectives and they might be naturally on different sides. But as industry is an important stakeholder of the university world it is worthwhile finding a compromise for the mutual benefit of all (Rovan, 2007).

European universities must be effective in their competition in information and communications technologies with the US and other world universities. This effectiveness can be achieved only through better cooperation with the ICT industry, in partnership with the relevant authorities.

\subsection{Universities in a Changing World}

Universities are moving in a changing world. Students are now less ready to accept what university delivers them if this does not fit with their set of values. There is a growing trend towards part-time studies. This is particularly true for computer related studies. The Digital Era started first in the universities bringing worldwide access to information and limiting the ex-cathedra approach to learning.

ICT is a vital element of the universities' infrastructure and courses tend to become world assets through Internet postings. In this way, and in many other ways, ICT has increased competition among universities. Europe should not be satisfied in this respect as US and Asian universities are making significant steps to update their courses and infrastructures.

Students have now unparalleled access to information and services and their expectancies are harder than ever to fulfil. The fast changes brought by on-line available teaching information changes the demographics of students. People may become students at any age and universities have to be prepared to offer them what they need.

Students are influenced in their demands by industry job offers. Skills need to be changed often, even in the same decade. ICT students graduating before 1995 were not exposed in university to some of today's concepts and technologies during their studies. Today, probably very few universities in the world still prepare skills in several old technologies, but the industry still needs them for legacy systems.

Universities are facing their most dramatic challenge yet, a highly connected, $24 \times 7$ digital worlds (Carrey, 2006). Industry creates competitors to universities, the so called 'infomediaries' (composite of information and intermediary) operating on-line $24 / 24$ with very user-friendly portals, financially attractive for 
students needing more skills and less formal diplomas. Online course use is growing with a double digit figure.

Universities preparing ICT skills are confronted with even more increased reliance on technology. There is a discrepancy between universities that may afford the technological change needed without industry support and universities that need this support. One of the barriers to updating technological equipment in universities is the cost. Most European universities cannot afford to update their hardware, software and telecom infrastructure on an annual basis.

\section{Universities and the ICT Industry}

\subsection{Universities and ICT High Innovation Rate}

Universities keep up with the new technological wave and new applications. Any lack of adaptation creates or widens the gap between the level of skills industry expects from fresh graduates and the actual skills produced by universities. The ICT industry innovates fast and it is not quite clear to many to what extent the institutions of higher education should adapt to new trends and technologies. This does not imply that universities should follow every industry hype blindly; they have to be able to look "beyond the hype".

Many universities rely on research as a primary focus. From a simplified perspective universities would focus on science and reflective research, while leaving the ICT industry to handle the applicative angle. Nevertheless, one might question whether the professors and instructors should remain focused on fairly narrow $\mathrm{PhD}$ subjects for decades, while possibly excluding new market-relevant features from their research and their classroom lectures. This seems to be the present state of the differences between what European Universities offer and European ICT industry needs in the work force.

There is a natural trend for universities to favour basic research and leave applied research to industry. In some cases, European universities have researchers able to perform any kind of project and seek industry contracts as an additional source of funding.

This is why one solution might be for the universities to grant easier access to more practical expert personnel. This would require that universities set up expert panels to evaluate the way in which new technological waves could add to the knowledge of existing research fields or even constitute the basis for entirely new research grounds. These panels should be affiliated with ICT industry personnel who would support the integration of academic studies with practical up-to-date exercises. Similar models have been initiated, with quite some success, in the past. CEPIS is in the position to act as catalyst of such panels. 


\subsection{Universities and Entrepreneurship (SME)}

ICT industry growth is fed by innovation carried out in small and medium enterprises. Most large ICT companies in the world, including Europe, started as SMEs. The SMEs act as innovation poles, they gather the skills and entrepreneurship attitudes that make ICT grow.

Universities are the main source of entrepreneurs. Most start their ventures, even before they graduate. European universities will better contribute to the increase of the SME sector in ICT, first by giving the students a solid scientific and technical background to allow them to innovate, and second by preparing them with the managerial skills needed in a small enterprise.

The universities are also the catalysts of entrepreneurship through technology parks established in the universities. This allows entrepreneurs to keep in contact with professors and benefit from their research output.

CEPIS believes that governments and the EU Commission should encourage, in any form, the development of such entrepreneurial centres around universities, nuclei of birth for many ICT companies in the industry.

\subsection{Research in Universities}

Universities are actively engaged in research. The research activity is the most important pillar sustaining teaching and bringing educators close to technology levels. The European R\&D framework programmes have largely succeeded in bringing universities and industry together in funding research that is useful to both (Katsikas, 2007). Speeding up the application of the research characteristic to ICT is seemingly benefiting the industry and forcing the universities to industrylike time scenarios.

Universities accelerate innovation in learning and research as they understand the marketplace and develop new types of learning systems. This report is focused on the educational role of the universities and the research aspects will not be further developed.

\subsection{Universities and ICT skills}

Universities are the main supplier of ICT skills demanded in the marketplace. ICT skills are divided into 3 categories by the European Commission (EU, 2007):

- ICT practitioner skills: these are the capabilities required for researching, developing, designing, strategic planning, managing, producing, consulting, marketing, selling, integrating, installing, administering, maintaining, supporting and servicing ICT systems. 
- ICT user skills: these are the capabilities required for the effective application of ICT systems and devices by the individual. ICT users apply systems as tools in support of their own work. User skills cover the use of common software tools and of specialised tools supporting business functions within industry. At the general level, they cover "digital literacy".

- E-business skills: these are the capabilities needed to exploit opportunities provided by ICT, notably the Internet; to ensure more efficient and effective performance of different types of organisations; to explore possibilities for new ways of conducting business/administrative and organisational processes; and/or establish new businesses.

The ICT industry counts on universities to produce professionals with ICT practitioner skills.

It is not the task of universities to prepare the people to use ICT applications, i.e. to have the user or E-business skills. However, Europe is not uniform as regards the level of digital literacy throughout the various countries and Ebusiness development. There are significant differences in levels of digital literacy among the $27 \mathrm{EU}$ countries and also compared with non-EU countries.

All universities, due to the high mobility of students, should ascertain the level of ICT skills that their junior freshmen students have on admission and bring all students to the necessary levels of basic user and eBusiness ICT skills. CEPIS considers ECDL to be an appropriate tool to asses this level.

This implication of universities in assessment or creation of basic skills is important as ICT is no longer a product or service for the elite, but as EU's eEurope states "Information Society is for all".

\subsection{Universities and the increasing scarcity of ICT professionals}

The strategic importance of the contemporary eSkills for Europe is widely recognized. Estimating supply and demand levels in 2010 and 2015 CEPIS believes that Europe would face shortages of up to 70,000 ICT practitioners, because of inadequate qualification and certification infrastructure (CEPIS 2007). Other reports confirm the gap in ICT skills preparation in Europe and underline that there is another gap in the so called e-business skills that mean effective competencies in using ICT and web technologies for business applications and for e-government applications.

Universities have the responsibility, not only for the qualitative aspects of ICT skills needed, but also to adapt and provide solutions for the increasing scarcity of ICT professionals within the market. The foreseeable lack of ICT skills in a few years shows that universities and policy makers are far from agreeing on what actions are urgent, both as diversification of ICT profiles and annual output. In some countries the supply/demand disequilibrium of ICT students is expected to deepen even more dramatically as the number of accepted ICT students continues 
to increase only marginally, or in some cases even drop. This contradicts the general trend for higher salaries and elite status of ICT graduates.

The different approaches of the universities and industry to the graduate skills required increases the gap between what universities offer and what the industry needs are. Industry has pragmatic goals and expectations. They look for young employees that are immediately employable and functional without much additional investments into their professional formation. So, they would like to influence curricula and make them more practical and relevant. Industry would like to identify the most promising students and potential employees in advance. An appropriate preliminary selection of graduates would significantly lower industry's risk in investments into new employees. In many companies this is the main objective in their relationship with the universities.

Within the university environment, especially in the new European Union states, there are still calls for a high level of student training for everybody. This is why some professors criticise the fact that very good students are hired by companies during their second or third grades, therefore neglecting theoretical education and moving away from a potential scientific career.

Conciliation among these divergent tendencies is vital for reducing the gap between the demand of industry and the offer of ICT graduates of the universities.

\subsection{Profile of ICT graduates}

The universities aim to produce well-qualified scientists and engineers with a strong scientific background in the basic sciences, thorough knowledge of current and emerging technology, coupled with communication skills, the ability to effectively interact and interoperate with scientists of other disciplines, and with management and leadership skills.

Normally this is what industry would need. This is not always the case and we see a gap between what ICT industry wants as a profile of graduates and what universities deliver. In fact, even industry has no homogenous requests. Large ICT companies ask for a solid scientific background as they have resources to further train their staff to undertake a broad range of tasks and projects. Smaller ICT companies prefer specialised ICT graduates ready-to-work providing return without further human resource training expenses. It is impossible to reconcile the two opposing requirements of the industry to have ICT graduates who are both flexible and immediately usable.

European universities train their ICT students in a variety of ways and a continuous process of interaction of universities with industry and society is of paramount importance. Every university has to decide what kind of professional they want to offer to the industry and adapt the curricula to best fit to that requirement within the type of profession chosen.

As regards non-ICT graduates, the industry (both large and small companies) demands graduates with basic ICT skills, e.g. having the ability to use ICT tools 
for simple tasks, and as an educational tool without further training. The same demand is presented by society at large, the administration, educational system, media, etc.

\subsection{Graduate level vs. certifications}

The industry needs highly skilled people ready to perform specific tasks and projects. A possible solution to this demand is the process of certifications. The ICT industry has developed a full series of vendor certifications asking people to pass examinations and tests. Most certifications are related to a particular company and product and are not suited for new graduates who will specialise later after some activity in the industry.

ICT graduates of European universities are characterised by a variety of specialisations and further certification is the only way of specialising them for specific tasks. It would be ideal if a graduate would have a certification, but this would mean a serious change of university role and duties towards students, making universities simply an industry service provider. This does not exclude a student to take a vendor certification while working in the industry or as an extra optional subject.

The main advantage of certifications can become their main drawback. From one side, a certification ensures that the defined competences are actually possessed by the certified (with a credibility given by the reliability of the certifying body). This increases the mobility of the certified, whose competences are easily recognised even abroad. From the other side, the certification hides any difference among certified people: it just tells the user that all certified people possess at least the competences defined by the syllabus, nothing about possible deeper levels of knowledge by one certified person with respect to another (Scarabotollo, 2007).

Universities have a natural tendency, for a variety of reasons, to keep away from vendor oriented industry certifications.

Industry vendor oriented certifications will continue when they relate to specific proprietary technologies in the ICT field, but those not related with proprietary technologies will end. Even in the USA it is viewed by many that industry certifications are useless from an employment point of view.

However, a more general certification based less on a specific company competence and more on general professional competence would possibly build a university-industry bridge.

Such a certification is proposed by CEPIS through EUCIP and in trying to bring closer graduate skills to EUCIP-like skills seems one obvious step to harmonise university-industry needs. 


\subsection{Curricula - is the Bologna process moving in the right direction?}

Curricula are what differentiate universities and define the level of professionalism of the future graduate.

The rapid advance of information and communications technology and the specific high rate of innovation bring industry to ask universities, almost unanimously, to update frequently their ICT curricula. The present curricula are judged by many in industry as not being adaptive enough to the new trends in ICT industry.

A major consideration is that the university curricula give too much attention to the theoretical training and less to industry internships and thus tend to produce super-skilled graduates (Baltac, 2007). The industry needs such people, but in a small number, as those being too highly skilled become unsatisfied with routine work, predominant in many companies.

Universities should produce both practitioners and research oriented people. The practitioners' level would be set through graduate and post-graduate master programmes. The research oriented students will benefit from $\mathrm{PhD}$ programmes.

The Bologna process which has just started may solve this problem, but it is still on the table. The Bologna agreement is expected to be implemented all over the European Union by the year 2010 and hopes to eliminate obstacles to the free circulation of people and help them to find jobs consistent with their education, regardless of their original country.

In general, universities claim to have adapted their curricula to the requirements of the Bologna recommendations. While some of them consider revisions to be made at the end of cycles $(3+2+3)$, others consider a curricula revision every year.

In some EU countries it is true that in ICT specialisations the new Bologna type scheme $(3+2+3)$ does not yet produce the best results. The first 3 years are filled with many courses repeating high school topics and students are not given the specialisation skills required by the industry, with dissatisfaction on both sides.

There are many opinions that the European tendency to move toward three-year bachelor degree programmes, may be alright for the humanities, but is certainly not acceptable for those areas of study which cannot be imagined without serious internships (medicine and engineering, including computing). Several universities in various countries declared that for computer science or engineering they will continue with 4 or 5 year bachelor programmes.

The Bologna process has to be continued with curricula updated for ICT graduates in the best interests of European universities and industry. Curricula have to be revisited systematically for the best harmonisation of graduates with market demands in Europe. This is related to continuing education and mobility. 


\subsection{The role of continuing education and mobility}

As an industry with short technological cycles, the ICT industry is particularly appropriate for lifelong learning. This is essential for e-skills competence-building and certification, as businesses face the need to respond to the shortening of the technology life-cycles in ICT and the accompanying obsolescence of related knowledge, skills and competences of their employees (Lueders, 2007). This opens new horizons to work based and non formal learning.

Updating professional training via a continuous educational process is not always undertaken by universities of most European countries, with some noted exceptions.

Master and doctoral studies are mostly aimed at students with high potential for research and rarely universities engage themselves in adult ICT education through university courses. One exception is represented by Executive MBA courses with ICT specialisations.

However, continuous education with short cycles is a necessity in ICT. On one hand, people who graduated 10-15 years ago received an education based on technologies that are now obsolete. Training in the new technologies, frequently requiring revising basic concepts, is left to industry training schools. Universities should be encouraged to offer master courses to students or graduates of other disciplines as a conversion course. Many of these could be offered through elearning.

On the other hand, the lack of skills brings into the ICT field an important number of non-ICT university graduates, mostly in emerging countries. They enter the field mostly retrained through industry certifications lacking basic training in computing concepts.

Universities could play a major role in the ICT education of people who have already been working in the industry for years or are under professional reconversion. They have to be opened to all groups needing ICT education.

New advances in e-learning technologies allow and favour distance learning, transforming the industry is a serious competitor of universities for adult and continuous education.

Proper financing can lead universities to offer high level free courses on new technologies, an approach reserved for the moment to several companies and professional associations. CEPIS believes that universities have to play a more important role in the post-graduate training of ICT professionals.

Mobility in the sense of movement of people between universities and industry is to be encouraged. Universities enjoy a large autonomy, but this should encourage people from industry to bring their fresh innovative ideas and experience to students and to people from universities to apply their ideas in industry.

This could change the opinion existing in many European universities, that the educators are civil servants with good and bad features, among which immovability, even when incompetent and lacking a business approach, and 
insisting on universities as essentially a scientific and research environment. This has a negative impact on updating with the needs of human resources by the ICT industry in particular, but one could say with the needs of industry and services in general.

CEPIS believes that mobility of people between universities and ICT industry is beneficial, will promote innovation, and has to be encouraged by a proper framework.

\section{Universities and ICT basic skills}

eEurope cannot be achieved without overall dissemination of basic ICT skills. Not only citizens are required to possess these skills, but the lack of these skills has profound economic impact especially for SMEs. Due to their limited resources, SMEs cannot invest in basic ICT education of their personnel and they have to be helped in this direction. e-Inclusion has different levels in the different countries of the European Union. There are still cases where not only secondary school graduates do not have these skills, but also some non-ICT university graduates do not have them (Baltac, 2008).

Training for basic skills for ICT and E-Business is not the task of universities, but belongs to secondary education. The largest part of the target group for spreading digital literacy is at an age where going back to secondary school is impossible. Universities cannot be asked to participate in the effort to disseminate basic ICT skills after student graduation, due to their highly qualified staff and their main research and education priorities.

Universities will bring a notable contribution to basic ICT skills dissemination, if all non-ICT graduates in Europe will have these basic skills. ICT and web technologies have to be considered as main enabling technologies for the preparation of all professions and in all industrial and social activities. Secondary and high schools should refocus their education programmes around these enabling technologies and redesign new partnerships with industry and public services for the dynamic preparation of the right skills in a permanently changing environment. Universities may help them with developing curricula and teaching materials.

The e-business skills are not also generally covered by universities; because they require a deep context knowledge originated by on the job experience and is frequently offered by some IT vendors as consultancy service. This is a category of professionals most appreciated by the market and it is also the most inclined to the certification approach.

CEPIS has developed a programme called European Computer Driving Licence - ECDL, now at Syllabus 5, based on the contribution of experts of national computer associations. We may strongly conclude that all European secondary 
school and university graduates have to be digitally literate, at least at the level of ECDL.

The role of universities in this area will end when all high school graduates will be at the required level of basic ICT skills.

\section{Role of EU and Governments in university-industry relationship}

Governments are the catalysts that can influence the 'universities/ICT industry' relationship. In Europe, a high number of universities are public universities, the role of the EU and Governments going far beyond being only catalysts of relations of the education system with industry. Particularly in the EU, where in addition to national governments the European Commission plays an important role with its financial incentives and different R\&D and regional programmes. Their regulatory role has an important function to maintain and support an educational infrastructure that would provide a sufficient number of educated people for all social and economic needs.

Governments and the European Commission can dramatically change universities/industry relations with focused incentives, mainly derived from their funding schemes.

ICT skills now have a well defined impact on economy and society. The lack of e-business and ICT skills at country level could lead to a potential loss of at least $1 \%$ of the GDP (Lamborghini, 2007) and the delay of major national or European e-projects. A focus on ICT skills is therefore an action of paramount importance for national Governments and the European Commission.

\section{CEPIS Call to action}

CEPIS is the most representative non-governmental body of ICT professionals in Europe with 37 member association from 33 European countries representing more than 300,000 professionals.

CEPIS recognises the main role of the universities in ICT education. Universities and the ICT industry are partners and the success of this partnership is sought by all. CEPIS believes that some actions are bringing closer the universities and industry expectations.

- CEPIS offers its services with the participation of the European Commission in a multi-stakeholder partnership as a pan-European mediator between universities and industry to define requirements for ICT skills at graduate, postgraduate and distance learning levels. CEPIS is the right group to bring together academia and industry in order that the output from the educational institutions satisfies the needs of the industry. 
- CEPIS offers its assistance in standardising and homogenising European mutual recognition of professionalism in the ICT sector.

- ICT curricula have to be adapted to reflect the actual needs of future graduates as industry employees. CEPIS offers its mediation through its EUCIP certification model that can be used as a tool for levelling up curricula of ICT studies in European universities.

- CEPIS believes that governments and the EU Commission should encourage, in any form, the development of entrepreneurial centres around universities nuclei of birth for many ICT companies in the industry.

- CEPIS supports the use of e-learning as a continuing professional development methodology.

- CEPIS considers that universities should be encouraged to offer master or other post-graduate conversion courses to non-ICT graduates.

- Universities have to check that their non-ICT students have the minimal ICT skills to act in the Information Society. CEPIS considers that its ECDL certification tool is very appropriate for checking the level attained by a non-ICT student.

- While recognising the positive role of the Bologna process, CEPIS asks for a review of the present content of curricula for ICT studies that could affect the future of the ICT industry by producing graduates without the proper theoretical background and practical training.

- CEPIS considers that the ICT vendor oriented professional certifications should be organised outside universities, offering graduates, after a certain experience gained in the field, a professional status. CEPIS offers its vendor neutral EUCIP certification programme enabling a unified assessment, across Europe, of professional level of ICT skills. Such vendor neutral certifications could be undertaken by universities at their evaluation.

- CEPIS believes that mobility of people between universities and the ICT industry is beneficial and it will promote innovation. This should be encouraged by a proper framework.

- CEPIS highly appreciates the e-Inclusion initiative of the European Commission. CEPIS thinks that all non-ICT students should be tested for their basic abilities to use ICT technologies at workplaces and at home. CEPIS considers its ECDL tool as an excellent solution for this assessment to be generalised in universities.

- CEPIS recognises the role of new countries that became EU members. They represent an important reservoir of ICT skills with proven competences and competitiveness. However, the e-Inclusion is not at the level of older members of the EU and ICT skills emigration affects these countries. CEPIS asks the European Commission to pay special attention to the ICT development needs of these countries, by implementing special programmes for ICT infrastructural development and ICT basic skills dissemination. CEPIS has member associations in all these countries and can define the actions and their implementation. 


\section{Acknowledgements}

The above position paper was developed by the author during September 2007 April 2008 as the chairman of a Task Force on Education set by the Council of the European Professional Societies CEPIS.

Contributions by comments and ideas by Fernando Piera - ATI Spain, Anders Linde - Dansk IT, Mary Sharp - ICS, Ernst Mayr - GI, Jos Baeten - NGI, Michael Schanz - VDE, Giulio Occhini - AICA and Andrew McGettrick - BCS are acknowledged. Special acknowledgment is to be done to members of CEPIS Execom, especially Geoff McMullen, Past President and Niko Schlamberger, President, who encouraged me and the work of the task force.

Debates at IT STAR 2nd IT STAR Workshop on Universities and ICT Industry UNICTRY 07, Genzano di Roma, 26 May 2007 and EU University Business Forum, Brussels, 28-29 February 2008 (European Commission 2008) had an important contribution to the clarification of the above ideas.

\section{References}

Baltac, Vasile, Universities and the Information Society, in L'Europe dans la Société de l'Information, Editions Larcier, Paris, 2008

Baltac, Vasile and Mihalca, Dan, On Romanian Experiences Related to Universities and ICT Industry, Proceedings of the 2nd IT STAR Workshop on Universities and ICT Industry UNICTRY 07, Genzano di Roma, 26 May 2007

Bavec, Cene, Universities and the ICT industry in search for innovativeness, Proceedings of the 2nd IT STAR Workshop on Universities and ICT Industry UNICTRY 07, Genzano di Roma, 26 May 2007

Carey, Patrick F., IBM's Higher Education Point of View - 2012, Executive White Paper Series, (2006), Available via IBM http://www-3.ibm.com/industries/education/doc/content/ /resource/thought/1737354110.html , Accessed 24 April 2008

CEPIS, Thinking ahead on e-skills for the ICT industry in Europe, eSkills Report, 2007 Available via CEPIS www.cepis.org/files/cepis/docs/20071217032722 Thinking\%20Ahead\%20on\%20eSkills\%20in\%20.doc Accessed 24 April 2008

European Commission, http://ec.europa.eu/education/policies/educ/business/index_en.html Accessed 1 May 2008

European Union, DG Enterprise and Industry, e-Skills FOR the 21st CENTURY:

FOSTERING COMPETITIVENESS, GROWTH AND JOBS, Available via EU http://ec.europa.eu/enterprise/ict/policy/ict-skills.htm Accessed 24 April 2008

Katsikas, Sokratis K., Universities and the ICT Industry, Higher Education and the ICT Industry, IT STAR Newsletter May 2007 Available in printed form and via IT STAR www.itstar.eu

Lamborghini, Bruno, Keynote Speech, Proceedings of the 2nd IT STAR Workshop on Universities and ICT Industry UNICTRY 07, Genzano di Roma, 26 May 2007

Lueders, Hugo, e-Skills Competences, Proceedings of the 2nd IT STAR Workshop on Universities and ICT Industry UNICTRY 07, Genzano di Roma, 26 May 2007

Rovan, Branislav , Universities and Industry, Proceedings of the 2nd IT STAR Workshop on Universities and ICT Industry UNICTRY 07, Genzano di Roma, 26 May 2007

Scarabottolo, Nello, Certification of ICT skills: a bridge between Universities and Industries, 2nd IT STAR Workshop, Genzano di Roma, 26 May 2007 